\title{
Ohmic heating does not influence the biochemical properties of Minas Frescal cheese but decreases uric acid levels in healthy Wistar rats
}

\author{
Ramon S. Rocha, ${ }^{1,2}$ Ramon Silva, ${ }^{1,2}$ Jonas T. Guimarães, ${ }^{2}$ Celso F. Balhtazar, ${ }^{2}$ Marcello R. Silveira, ${ }^{2}$ \\ Aline A. Martins, ${ }^{3}$ Vitória P. Rojas, ${ }^{3}$ Juliana S. Graça, ${ }^{4}$ Tatiana C. Pimentel, ${ }^{5}$ Erick A. Esmerino, ${ }^{2}$ \\ Anderson S. Sant'Ana, ${ }^{4}$ Daniel Granato, ${ }^{6}$ Mônica Q. Freitas, ${ }^{2}$ Márcio E. Barros, ${ }^{3}$ Márcia C. Silva, ${ }^{1}$ \\ and Adriano G. Cruz ${ }^{1 *}$ \\ ${ }^{1}$ Instituto Federal de Educação, Ciência e Tecnologia do Rio de Janeiro (IFRJ), Departamento de Alimentos, 20270-021, Rio de Janeiro, Brazil \\ ${ }^{2}$ Universidade Federal Fluminense (UFF), Faculdade de Veterinária, 24230-340 Niterói, Brazil \\ ${ }^{3}$ Universidade Federal da Grande Dourados (UFGD), Faculdade de Ciências da Saúde, 79800-000 Dourados, Brazil \\ ${ }^{4}$ Universidade Estadual de Campinas (UNICAMP), Faculdade de Engenharia de Alimentos (FEA), 13083-862, Campinas, Brazil \\ ${ }^{5}$ Instituto Federal de Educação, Ciência e Tecnologia do Paraná (IFPR), 87703-536, Paranavaí, Brazil \\ ${ }^{6}$ Natural Resources Institute Finland, Food Science and Experimental Nutrition, Maarintie Open Innovation House, Espoo, Finland 02150
}

\begin{abstract}
The objective of this study was to evaluate the effects of the consumption of Minas Frescal cheese $(2 \mathrm{~g}$ for 15 d) produced with pasteurized milk or milk subjected to ohmic heating on the health variables (biochemical, hematological, and uric acid levels) of rats, as well as on the identity variables and proteolysis indices of cheese. Three groups of rats ( $\mathrm{n}=6$ per group) were studied, as follows: control group, without cheese consumption $(\mathrm{CON})$, rats fed Minas Frescal cheese produced with milk pasteurized by conventional technology (PC, 72 to $75^{\circ} \mathrm{C}$ for $15 \mathrm{~s}$ ), and rats fed Minas Frescal cheese produced with milk subjected to ohmic heating (OHC, $8 \mathrm{~V} / \mathrm{cm}, 72$ to $75^{\circ} \mathrm{C}$ for $\left.15 \mathrm{~s}\right)$. Ohmic heating did not alter the macronutrient levels (moisture, fat, protein) of the cheeses, but an increase in the proteolysis index was observed. For both cheeses, no significant differences were observed for feed intake (139 to $143 \mathrm{~g} / \mathrm{d}$ ), water consumption (196 to $206 \mathrm{~mL} / \mathrm{d}$ ), or final animal weight (236 to $252 \mathrm{~g}$ ), and no changes were detected in hematological variables (counts of red blood cells, hemoglobin, leukocytes, and platelets) or levels of potassium, calcium, magnesium, urea, creatinine, total cholesterol, high-density lipoprotein cholesterol, blood glucose, and bilirubin (total, direct, and indirect) of rats. In addition, both cheeses led to a reduction of serum triglycerides and an increase in monocyte, eosinophil, and basophil levels. However, consumption of $\mathrm{OHC}$ resulted in decreased sodium, uric acid, and lymphocyte levels. The present results suggest that ohmic heating in the
\end{abstract}

Received October 6, 2019.

Accepted February 3, 2020.

*Corresponding author: food@globo.com processing of Minas Frescal cheese has positive effects on the health of healthy rats.

Key words: Minas Frescal cheese, ohmic heating, uric acid, rats

\section{INTRODUCTION}

Minas Frescal cheese is one of the most popular cheeses in Brazil, characterized by its high yield, high water activity, slightly acidic $\mathrm{pH}(\mathrm{pH}=5.0)$, low salt content, absence of synthetic preservatives, and easy technological processing (Sperry et al., 2018). It is a fresh cheese obtained by enzymatic coagulation of milk using rennet or other coagulant enzymes, with or without the addition of starter cultures (Pimentel et al., 2017). For Minas Frescal cheese manufacturing, raw milk is conventionally subjected to a thermal processing called pasteurization, ensuring the microbiological safety of the product (Cappato et al., 2017). However, pasteurization can lead to negative changes in the sensory, nutritional, and physicochemical properties of processed products (Coutinho et al., 2018), which can be prevented by the use of emerging technologies such as ohmic heating (OH; Cappato et al., 2017).

Ohmic treatment promotes rapid and homogeneous heating of milk by converting electrical energy to thermal energy, resulting in greater retention of thermosensitive compounds and sensory attributes due to exposure to a lower thermal load (Cappato et al., 2018). In addition, $\mathrm{OH}$ is characterized by uniform heat generation, lower capital cost (not requiring a boiler and a heat transfer surface), lower maintenance cost (no moving parts), and ease of process control through instant switch-on and shutdown (Makroo et al., 2020).

Consumption of Minas Frescal cheese has been associated with several health benefits, such as improved 
lipid indexes (Sperry et al., 2018), lowered blood pressure (Lollo et al., 2015), constipation relief (Favretto et al., 2013), and increased immunity (Lollo et al., 2012), although studies have focused on cheeses containing probiotics and produced with pasteurized milk. To the best of our knowledge, no studies have yet been performed on Minas Frescal cheese made with milk subjected to $\mathrm{OH}$. Thus, the objective of this study was to evaluate the effects of continuous consumption of Minas Frescal cheeses made with pasteurized milk or milk subjected to $\mathrm{OH}$ on the health variables (biochemical and hematological properties and uric acid level) in healthy rats.

\section{MATERIALS AND METHODS}

\section{Milk Processing}

Cooled raw milk (10 L, 3.4\% fat) was purchased from the Barra Mansa Milk Producers Cooperative (Barra Mansa, Brazil) and subjected to conventional pasteurization or $\mathrm{OH}$ treatment. For conventional pasteurization, milk was heated to 72 to $75^{\circ} \mathrm{C}$ for $15 \mathrm{~s}$, using a water bath. The $\mathrm{OH}$ equipment consisted of 2 iron-containing electrodes $(9 \mathrm{~cm}$ long, made of stainless steel type 316), a power supply, a heating bowl, a thermocouple, a stirrer, and 3 multimeters for measuring the variables (temperature, voltage, and alternating current generation). Milk was submitted to ohmic treatment of $8 \mathrm{~V} / \mathrm{cm}$ until reaching 72 to $75^{\circ} \mathrm{C}$ for $15 \mathrm{~s}$. Then the samples were immediately immersed in an ice bath to promote rapid cooling $\left(7^{\circ} \mathrm{C}\right)$.

\section{Manufacture of Minas Frescal Cheese}

Minas Frescal cheese was produced according to the methodology described by Dantas et al. (2016). Calcium chloride $(0.2 \mathrm{~g} / 100 \mathrm{~g}$; Labsynth, Sao Paulo, Brazil) and coagulant (3 g/L; Halamix, Chr. Hansen, Hørsholm, Denmark) were added to the pasteurized or OH-treated milk, which was stirred and then kept at rest for $35 \mathrm{~min}$ at $37^{\circ} \mathrm{C}$ for coagulation. The curd was then cut, the whey was removed, and the remaining curd was placed in 250-g plastic molds. The cheeses were dry-salted $(0.8 \mathrm{~g}$ of salt per $100 \mathrm{~g}$ of cheese; $\mathrm{NaCl}$ from Labsynth), packaged, and stored in a refrigerated chamber at $5^{\circ} \mathrm{C}$.

\section{Physicochemical Composition and Proteolytic Activity}

The physicochemical composition of the cheese (moisture, protein, and fat levels) was determined using the traditional methods proposed by AOAC International (2002). The moisture content was determined by drying
$5 \mathrm{~g}$ of sample at 100 to $105^{\circ} \mathrm{C}$ for $24 \mathrm{~h}$. The protein content was determined via the Kjeldahl method, multiplying the nitrogen content by the conversion factor 6.38. Fat content was determined through the Gerber method. All results were expressed in grams per 100 $\mathrm{g}$ of cheese. Proteolytic activity was determined after reaction with a reactive solution (o-phthaldialdehyde) containing sodium dodecyl sulfate, dithiothreitol, sodium tetraborate decetrate, ophthalaldehyde, and ethanol. Amino acids and peptides were quantified by absorbance readings of $o$-phthaldialdehyde derivatives at $340 \mathrm{~nm}$ (Sperry et al., 2018).

\section{Clinical Study}

The in vivo experiment used 8- to 10-wk-old male rats (Rattus norvergicus, Wistar variety) weighing 230 to $260 \mathrm{~g}$. This study was approved by the Animal Experimentation Committee of the Federal University of Grande Dourados (Dourados, Brazil), under protocol $21 / 2018$. The animals were supplied by the Federal University of Grande Dourados Central Biottery, kept under controlled conditions $\left(22^{\circ} \mathrm{C} ; 40\right.$ to $60 \%$ humidity, and 12-h light-dark cycle), individually identified, and housed in polypropylene cages with feed and water ad libitum.

The experimental design is shown in Figure 1. Three groups ( $\mathrm{n}=6$ per group) were studied, as follows: the control group $(\mathbf{C O N})$ was fed no cheese; the $\mathbf{P C}$ group was fed cheese made with pasteurized milk (2 g/d); and the $\mathbf{O H C}$ group was fed cheese made with milk subjected to ohmic heating $(2 \mathrm{~g} / \mathrm{d})$. Cheese was administered at the end of the dark cycle, offered along with the commercial ration. The experiment lasted $14 \mathrm{~d}$.

Animals were anesthetized with xylazine ( 8 to 15 $\mathrm{mg} / \mathrm{kg}$ ) associated with ketamine (60 to $80 \mathrm{mg} / \mathrm{kg}$ ) via intraperitoneal injection, and blood was collected via cardiac puncture (1 to $2 \mathrm{~mL}$ ). Blood was used to measure dosage of urea, creatinine, sodium, potassium, and magnesium, total cholesterol and fractions, total bilirubin and fractions, uric acid, blood glucose, and hematological variables (red blood cells, hemoglobin, leukocytes, platelets, monocytes, eosinophils, basophils, neutrophils, and lymphocytes). Dosing was performed via standardized methods, specific to each analysis, performed at the Clinical Analysis Laboratory of the School Hospital at the Federal University of Grande Dourados.

\section{Statistical Analysis}

We used ANOVA to compare the responses between groups, and means were compared using Tukey's test, with $P<0.05$ as the significance level. Statistical anal- 


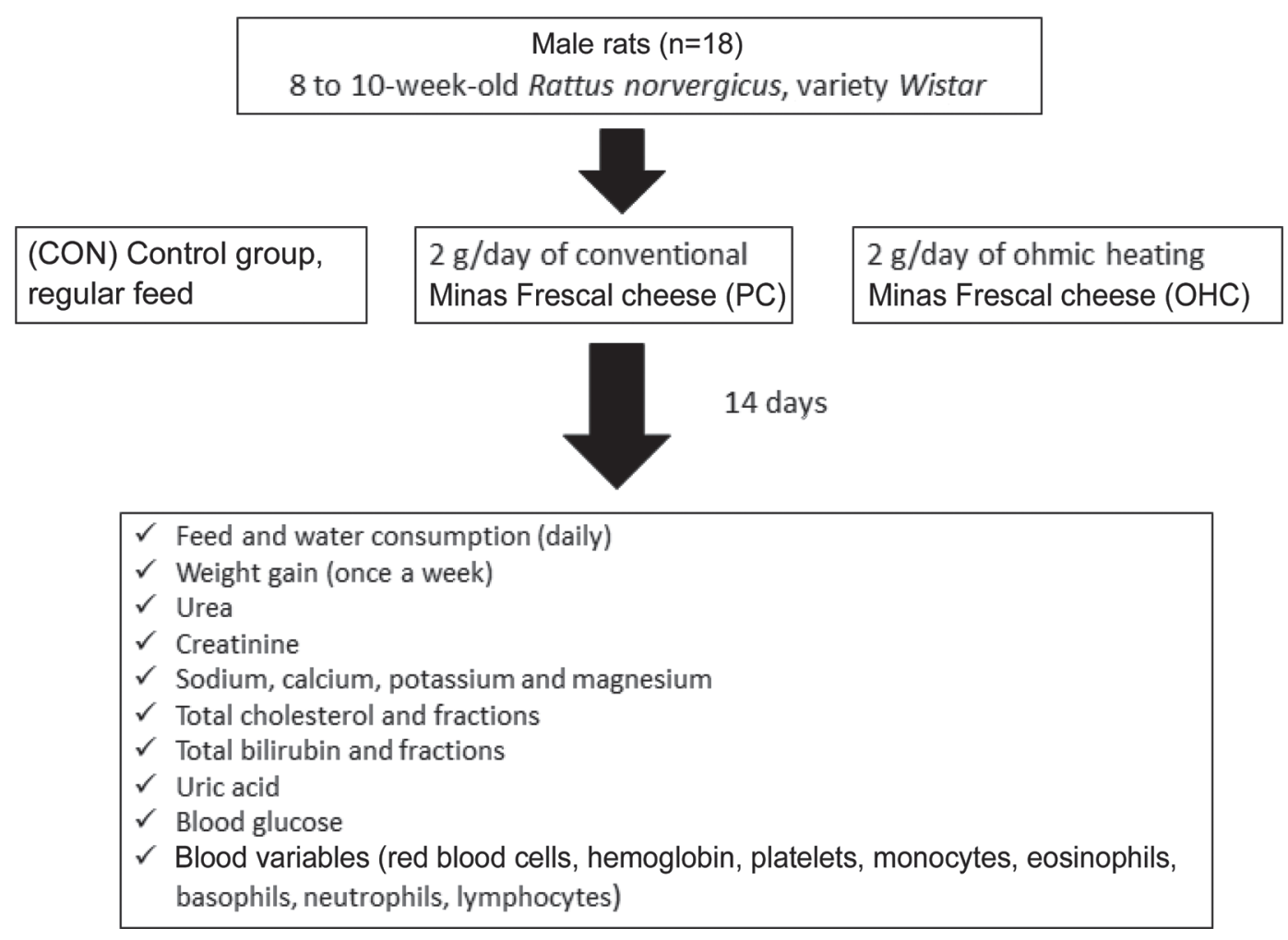

Figure 1. Experimental design to evaluate the effects in rats of consuming Minas Frescal cheese produced with pasteurized milk or milk subjected to ohmic heating on the health variables of rats, as well as on identity variables and proteolysis indices of cheese.

yses were performed using GraphPad Prism software, version 5.0, for Windows (GraphPad Software Inc., La Jolla, CA).

\section{RESULTS AND DISCUSSION}

\section{Physicochemical Composition and Proteolytic Activity}

Table 1 shows the physicochemical composition and proteolytic activity of the cheeses. Both types of Minas Frescal cheeses presented (per $100 \mathrm{~g}$ of cheese) 57 to $58 \mathrm{~g}$ of moisture, 16.9 to $17.2 \mathrm{~g}$ of protein, and 16 to $16.4 \mathrm{~g}$ of lipids, corroborating previous studies (Dantas et al., 2016; Sperry et al., 2018). We found no effect of the type of milk processing (pasteurization or $\mathrm{OH}$ ) on the physicochemical composition of the cheeses $(P$ $>0.05)$. The $\mathrm{OHC}$ cheese had higher proteolytic activity values compared with $\mathrm{PC}(0.69$ vs. $0.43, P<$ 0.05). Ohmic treatment can promote changes in the conformation of enzymes, leading to either increase or reduction of enzyme activity (Cappato et al., 2018) as well as an increase in protein hydrolysis (Ferreira et al., 2019). These changes can lead to the formation of small peptides. Higher proteolysis may be a positive result, as it represents greater digestibility and higher concentration of bioactive peptides in the $\mathrm{OHC}$ cheese (Sperry et al., 2018).

\section{Clinical Study}

Table 2 presents the results of feed and water consumption and the final weights of the studied rats. The rats consumed 138.8 to $142.8 \mathrm{~g} / \mathrm{d}$ of feed and 195.5 to $206.4 \mathrm{~mL} / \mathrm{d}$ of water and presented a final weight from 236.4 to $251.7 \mathrm{~g}$. We found no effect of cheese consumption (PC or $\mathrm{OHC}$ ) on the amount of feed or water ingested or on the final animal weight $(P>0.05)$. The results indicate that although food intake was higher

Table 1. Chemical composition and proteolytic activity of Minas Frescal cheeses made with conventional pasteurized milk (PC) or milk treated with ohmic heating $(\mathrm{OH}) ;$ mean $\pm \mathrm{SD}, \mathrm{n}=6$ per group

\begin{tabular}{lcc}
\hline Item $^{1}$ & PC & OH \\
\hline Moisture & $57.0 \pm 0.62^{\mathrm{a}}$ & $58.0 \pm 0.57^{\mathrm{a}}$ \\
Protein & $17.2 \pm 0.63^{\mathrm{a}}$ & $16.9 \pm 0.89^{\mathrm{a}}$ \\
Lipid & $16.4 \pm 0.81^{\mathrm{a}}$ & $16.0 \pm 0.40^{\mathrm{a}}$ \\
Proteolytic activity & $0.43 \pm 0.12^{\mathrm{b}}$ & $0.69 \pm 0.04^{\mathrm{a}}$
\end{tabular}

$\overline{\mathrm{a}, \mathrm{b}}$ Different superscript letters in the same row indicate significant differences among treatments $(P<0.05)$.

${ }^{1}$ Moisture, protein, and lipid contents are expressed in grams per $100 \mathrm{~g}$ of cheese. Proteolytic activity is absorbance at $340 \mathrm{~nm}$. 
Table 2. Feed and water consumption and final weight of experimental rats: control (CON) rats were fed no cheese in addition to standard diet, PC group was fed Minas Frescal cheese made with conventional pasteurized milk, and $\mathrm{OHC}$ group was fed Minas Frescal cheese made with milk treated with ohmic heating $(\mathrm{n}=6$ per group; values are mean $\pm \mathrm{SD}$ )

\begin{tabular}{lccc}
\hline Item & CON & PC & OHC \\
\hline Final weight $(\mathrm{g})$ & $238.5 \pm 9.25^{\mathrm{a}}$ & $251.7 \pm 4.196^{\mathrm{a}}$ & $236.4 \pm 5.61^{\mathrm{a}}$ \\
Feed consumption $(\mathrm{g} / \mathrm{d})$ & $141.8 \pm 2.74^{\mathrm{a}}$ & $142.8 \pm 3.85^{\mathrm{a}}$ & $138.8 \pm 3.77^{\mathrm{a}}$ \\
Water consumption $(\mathrm{mL} / \mathrm{d})$ & $206.4 \pm 4.72^{\mathrm{a}}$ & $203.6 \pm 2.87^{\mathrm{a}}$ & $195.5 \pm 8.13^{\mathrm{a}}$ \\
\hline
\end{tabular}

${ }^{\mathrm{a}}$ Means with identical superscript letters within a row indicate no significant differences among treatments $(P$ $>0.05)$.

in the diets containing cheese, there was no significant effect on body weight gain (Bouton et al., 2019).

Table 3 presents the results of the biochemical variables of uric acid levels in rats. We found no effect of cheese consumption on levels of potassium, calcium, magnesium, urea, creatinine, total cholesterol, highdensity lipoprotein (HDL) cholesterol, direct or indirect bilirubin, and glucose $(P>0.05)$. Cheese consumption reduced serum triglycerides $(P<0.05)$, regardless of the type of cheese. Cheese contains compounds that can inhibit fatty acid desaturation, thereby reducing the availability of monounsaturated fatty acids, which are the preferred substrates for the synthesis of triglycerides, cholesterol esters, and phospholipids (Høstmark and Lunde, 2012). In addition, the calcium in cheese may interact with fatty acids, resulting in the formation of insoluble soaps and excretion in feces, contributing to the decrease in triglycerides (Higurashi et al., 2016). The reduction of triglyceride levels is interesting from a functional point of view.

Continuous consumption of $\mathrm{OHC}$ led to a reduction of sodium and uric acid levels $(P<0.05)$ in the studied rats. Lower levels of uric acid and sodium in the blood of the rats fed $\mathrm{OHC}$ are probably due to their higher proteolytic capacity (Table 1) and, consequently, to a higher number of bioactive peptides. Milk proteins, especially short-chain peptides, are able to reduce serum uric acid concentrations, increasing the amount of uric acid excretion (Kaneko et al., 2014). The consumption of these peptides can also be related to increased vasodilation and reduction of blood sodium levels (Schiering et al., 2016). Indeed, a recent study showed that Minas Frescal cheese processed using $\mathrm{OH}$ presented greater ACE inhibitory activity compared with cheese manufactured using conventional processing (25.4 to $26.7 \%$ vs. $12.5 \%$, respectively; $P<0.05$; Rocha et al., 2020). In addition, peptide profiling in cheeses manufactured using ohmic heating revealed higher numbers of bioactive peptides, identified using the mass-to-charge ratio $(m / z)$. Ohmic-heated cheese presented 21 to 34 peptides, as opposed to 18 in CP cheese; 7 of these peptides are responsible for the discrimination of the treatments, notably 3 with ACE-inhibitory activity: $\kappa-\mathrm{CN} \mathrm{f}\left(157-163, m / z\right.$ 780), $\alpha_{\mathrm{S} 1}-\mathrm{CN} \mathrm{f}(18-23, m / z$ 791), and $\beta-\mathrm{CN} \mathrm{f}(193-202, \mathrm{~m} / z$ 1,158), all found exclusively in $\mathrm{OH}$ cheeses (Rocha et al., 2019). Thus, cheeses made

Table 3. Biochemical variables of experimental rats: control $(\mathrm{CON})$ rats were fed no cheese in addition to standard diet, PC group was fed Minas Frescal cheese made with conventional pasteurized milk, and OHC group was fed Minas Frescal cheese made with milk treated with ohmic heating $(\mathrm{n}=6$ per group; values are mean $\pm \mathrm{SD})$

\begin{tabular}{lcrr}
\hline Item & CON & PC & OHC \\
\hline Sodium (mmol/dL) & $142.6 \pm 0.54^{\mathrm{a}}$ & $141.1 \pm 0.46^{\mathrm{a}}$ & $140.6 \pm 0.57^{\mathrm{b}}$ \\
Potassium (mmol/L) & $4.72 \pm 0.10^{\mathrm{a}}$ & $4.65 \pm 0.15^{\mathrm{a}}$ & $5.08 \pm 0.34^{\mathrm{a}}$ \\
Calcium $(\mathrm{mg} / \mathrm{dL})$ & $10.62 \pm 0.12^{\mathrm{a}}$ & $10.25 \pm 0.17^{\mathrm{a}}$ & $10.32 \pm 0.289^{\mathrm{a}}$ \\
Magnesium (mg/dL) & $2.85 \pm 0.145^{\mathrm{a}}$ & $2.76 \pm 0.10^{\mathrm{a}}$ & $2.54 \pm 0.04^{\mathrm{a}}$ \\
Urea (mg/dL) & $54.12 \pm 2.25^{\mathrm{a}}$ & $51.85 \pm 2.69^{\mathrm{a}}$ & $53.13 \pm 1.93^{\mathrm{a}}$ \\
Creatinin (mg/dL) & $0.34 \pm 0.01^{\mathrm{a}}$ & $0.40 \pm 0.02^{\mathrm{a}}$ & $0.39 \pm 0.02^{\mathrm{a}}$ \\
Cholesterol (mg/dL) & $54.00 \pm 5.81^{\mathrm{a}}$ & $53.00 \pm 4.34^{\mathrm{a}}$ & $55.00 \pm 4.42^{\mathrm{a}}$ \\
Triglyceride (mg/dL) & $70.33 \pm 10.19^{\mathrm{a}}$ & $32.98 \pm 3.36^{\mathrm{b}}$ & $47.20 \pm 3.99^{\mathrm{b}}$ \\
HDL cholesterol (mg/dL) & $60.83 \pm 5.9^{\mathrm{a}}$ & $61.17 \pm 3.48^{\mathrm{a}}$ & $58.6 \pm 3.61^{\mathrm{a}}$ \\
Glycemia (no fasting; mg/dL) & $295.1 \pm 14.20^{\mathrm{a}}$ & $273.1 \pm 20.20^{\mathrm{a}}$ & $320.8 \pm 17.56^{\mathrm{a}}$ \\
Bilirubin (total; mg/dL) & $0.06 \pm 0.08^{\mathrm{a}}$ & $0.06 \pm 0.09^{\mathrm{a}}$ & $0.08 \pm 0.06^{\mathrm{a}}$ \\
Bilirubin (indirect; mg/dL) & $0.04 \pm 0.01^{\mathrm{a}}$ & $0.05 \pm 0.01^{\mathrm{a}}$ & $0.06 \pm 0.04^{\mathrm{a}}$ \\
Bilirubin (direct; mg/dL) & $0.01 \pm 0.003^{\mathrm{a}}$ & $0.01 \pm 0.004^{\mathrm{a}}$ & $0.01 \pm 0.003^{\mathrm{a}}$ \\
Uric acid (mg/dL) & $0.8 \pm 0.11^{\mathrm{a}}$ & $1.2 \pm 0.11^{\mathrm{a}}$ & $0.1 \pm 0.15^{\mathrm{b}}$ \\
\hline
\end{tabular}

${ }^{\mathrm{a}, \mathrm{b}}$ Different superscript letters in the same row indicate significant differences among treatments $(P<0.05)$.

${ }^{1} \mathrm{HDL}=$ high-density lipoprotein. 
with milk subjected to ohmic treatment have antihyperuricemic properties and may help in controlling hypertension. Hyperuricemia is a metabolic disease resulting from overproduction of uric acid or from a disorder of uric acid excretion in the body. Excessive levels of uric acid in the blood can cause nephrolithiasis and gout, resulting in hyperlipidemia, hypertension, type II diabetes, and cardiovascular disease ( $\mathrm{Li}$ et al., 2018). High blood pressure increases the risk of stroke, heart attack, heart failure, kidney damage, and vision loss (Wright et al., 2018).

We found no effect of cheese consumption on the counts of red blood cells, hemoglobin, leukocytes, and platelets of rats $(P>0.05)$. Cheese consumption increased the number of monocytes, eosinophils, and basophils $(P<0.05)$, and a more pronounced effect was observed for the conventional cheeses $(\mathrm{PC})$. In addition, the number of lymphocytes decreased $(P<0.05)$. Basophils release mediators capable of increasing vascular permeability and inducing migration of inflammatory cells (neutrophils and macrophages). Inflammatory responses are also associated with increased eosinophils (Zakharenko et al., 2017). An increase in neutrophil levels was observed only for the consumption of the control cheese made with pasteurized milk (PC, $P<$ $0.05)$. Increased neutrophil levels in the blood are an indicator of inflammatory processes (Zakharenko et al., 2017). The results indicate that cheese intake, regardless of the type of milk used in cheese manufacture, may have the ability to increase inflammatory processes in rats. However, this increase was smaller in cheeses made with milk subjected to ohmic heating, which represents an advantage of this technology.

\section{CONCLUSIONS}

The consumption of Minas Frescal cheese made with milk subjected to ohmic heating may be beneficial for hyperuricemic individuals, maintaining uric acid levels and preventing progression of gout. In addition, it can contribute to controlling hypertension. The present study is the first in vivo investigation involving the consumption of Minas Frescal cheese made with milk subjected to ohmic heating, and the results are important for the dairy industry, as they indicate that this alternative heat treatment may result in health benefits.

\section{ACKNOWLEDGMENTS}

This study was financed in part by the Coordenação de Aperfeiçoamento de Pessoal de Nível Superior Brasil (CAPES, Brasília), Finance Code 001, Fundação de Amparo ao Apoio a Pesquisa no Rio de Janeiro
(FAPERJ, Brazil), and the Instituto Federal de Educação, Ciência e Tecnologia do Rio de Janeiro (IFRJ, Rio de Janeiro, Brazil). A. S. Sant'Ana, M. Q. Freitas, E. A. Esmerino, M. C. Silva, and A. G. Cruz also thank the Conselho Nacional de Desenvolvimento Científico e Tecnológico (CNPq, Brasília, Brazil). The authors declare that they have no conflicts of interest.

\section{REFERENCES}

AOAC International. 2002. Official Methods of Analysis. 17th ed. AOAC International, Gaithersburg, MD.

Bouton, Y., R. Berges, S. Cabaret, E. Beuvier, L. Bretillon, and O. Berdeaux. 2019. Effect of a diet supplemented with fat from pressed-cooked cheese, butter or palm oil on blood lipids, faecal fat excretion and body composition of rats. Int. Dairy J. 95:44-49. https://doi.org/10.1016/j.idairyj.2019.02.018.

Cappato, L. P., M. V. Ferreira, J. T. Guimaraes, J. B. Portela, A. L. R. Costa, M. Q. Freitas, R. L. Cunha, C. A. F. Oliveira, G. D. Mercali, L. D. F. Marzack, and A. G. Cruz. 2017. Ohmic heating in dairy processing: Relevant aspects for safety and quality. Trends Food Sci. Technol. 62:104-112. https://doi.org/10.1016/j.tifs.2017 .01 .010 .

Cappato, L. P., M. V. S. Ferreira, J. Moraes, R. P. Pires, R. S. Rocha, R. Silva, R. P. C. Neto, M. I. B. Tavares, M. Q. Freitas, F. N. Rodrigues, V. M. A. Calado, R. S. L. Raices, M. C. Silva, and A. G. Cruz. 2018. Whey acerola-flavoured drink submitted ohmic heating: Bioactive compounds, antioxidant capacity, thermal behavior, water mobility, fatty acid profile and volatile compounds. Food Chem. 263:81-88. https://doi.org/10.1016/j.foodchem.2018 .04 .115 .

Coutinho, N. M., M. R. Silveira, R. S. Rocha, J. Moraes, M. V. S. Ferreira, T. C. Pimentel, M. Q. Freitas, M. C. Silva, R. S. L. Raices, C. S. Ranadheera, F. O. Borges, S. P. Mathias, F. A. N. Fernandes, S. Rodrigues, and A. G. Cruz. 2018. Cold plasma processing of milk and dairy products. Trends Food Sci. Technol. 74:56-68. https://doi.org/10.1016/j.tifs.2018.02.008.

Dantas, A. B., V. F. Jesus, R. Silva, C. N. Almada, E. A. Esmerino, L. P. Cappato, M. C. Silva, R. S. L. Raices, R. N. Cavalcanti, C. C. Carvalho, A. S. Sant'Ana, H. M. A. Bolini, M. Q. Freitas, and A. G. Cruz. 2016. Manufacture of probiotic Minas Frescal cheese with Lactobacillus casei Zhang. J. Dairy Sci. 99:18-30. https://doi .org/10.3168/jds.2015-9880.

Favretto, D. C., B. Pontin, and T. R. Moreira. 2013. Effect of the consumption of a cheese enriched with probiotic organisms (Bifidobacterium lactis bi-07) in improving symptoms of constipation. Arq. Gastroenterol. 50:196-201. https://doi.org/10.1590/S0004 -28032013000200035 .

Ferreira, M. V. S., L. P. Cappato, R. Silva, R. S. Rocha, J. T. Guimarães, C. F. Balthazar, E. A. Esmerino, M. Q. Freitas, F. N. Rodrigues, D. Granato, R. P. C. Neto, M. I. B. Tavares, P. H. F. Silva, R. S. L. Raices, M. C. Silva, and A. G. Cruz. 2019 Ohmic heating for processing of whey-raspberry flavored beverage. Food Chem. 297:125018. https://doi.org/10.1016/j.foodchem.2019 .125018 .

Higurashi, S., A. Ogawa, T. Y. Nara, K. Kato, and Y. Kadooka. 2016. Cheese consumption prevents fat accumulation in the liver and improves serum lipid parameters in rats fed a high-fat diet. Dairy Sci. Technol. 96:539-549. https://doi.org/10.1007/s13594-016-0288-z.

Høstmark, A. T., and M. S. Lunde. 2012. Cheese can reduce indexes that estimate fatty acid desaturation. Results from the Oslo Health Study and from experiments with human hepatoma cells. Appl. Physiol. Nutr. Metab. 37:31-39. https://doi.org/10.1139/h11-123.

Kaneko, K., Y. Aoyagi, T. Fukuuchi, K. Inazawa, and N. Yamaoka. 2014. Total purine and purine base content of common foodstuffs for facilitating nutritional therapy for gout and hyperuricemia. Biol. Pharm. Bull. 37:709-721. https://doi.org/10.1248/bpb.b13 $-00967$. 
Li, Y., X. Kang, Q. Li, C. Shi, Y. Lian, E. Yuan, M. Zhou, and J. Ren. 2018. Anti-hyperuricemic peptides derived from bonito hydrolysates based on in vivo hyperuricemic model and in vitro xanthine oxidase inhibitory activity. Peptides 107:45-53. https://doi.org/10 .1016/j.peptides.2018.08.001.

Lollo, P. C., P. N. Morato, C. S. Moura, C. N. Almada, T. L. Felicio, E. A. Esmerino, M. E. Barros, J. Amaya-Farfán, A. S. Sant'Ana, R. S. L. Raices, M. C. Silva, and A. G. Cruz. 2015. Hypertension parameters are attenuated by the continuous consumption of probiotic Minas cheese. Food Res. Int. 76:611-617. https://doi.org/10 .1016/j.foodres.2015.07.015.

Lollo, P. C. B., A. G. Cruz, P. N. Morato, C. S. Moura, L. B. Carvalho-Silva, C. A. F. D. Oliveira, J. A. F. Faria, and J. AmayaFarfan. 2012. Probiotic cheese attenuates exercise-induced immune suppression in Wistar rats. J. Dairy Sci. 95:3549-3558. https://doi .org/10.3168/jds.2011-5124.

Makroo, H. A., N. K. Rastogi, and B. Srivastava. 2020. Ohmic heating assisted inactivation of enzymes and microorganisms in foods: A review. Trends Food Sci. Technol. 97:451-464.

Pimentel, T. C., V. A. Marcolino, C. E. Barão, S. J. Klososki, and M. Rosset. 2017. Minas Frescal cheese as a probiotic carrier. Pages 1-32 in Bioactive Molecules in Food. Springer, United Kingdom.

Rocha, R. S., R. A. O. Paula, L. Rodrigues-Robeiro, R. S. L. Raices, M. C. Silva, T. Verano-Braga, and A. G. Cruz. 2019. Ohmic heating improves peptide profile in Minas Frescal cheese processing. Abstracts of the 1st CIAPep-Ibero-American Congress on Bioactive Peptides. Campinas, São Paulo, Brazil.

Rocha, R. S., R. Silva, J. T. Guimarães, C. F. Balthazar, T. C. Pimentel, R. P. C. Neto, M. I. B. Tavares, E. A. Esmerino, M. Q.
Freitas, L. P. Cappato, R. N. Cavalcanti, F. N. Rodrigues, R. S. L. Raices, M. C. Silva, and A. G. Cruz. 2020. Possibilities for using ohmic heating in Minas Frescal cheese production. Food Res. Int. 131:109027. https://doi.org/10.1016/j.foodres.2020.109027.

Schiering, N., A. D'Arcy, F. Villard, P. Ramage, C. Logel, F. Cumin, G. M. Ksander, C. Wiesmann, R. G. Karki, and M. Mogi. 2016. Structure of neprilysin in complex with the active metabolite of sacubitril. Sci. Rep. 6:27909. https://doi.org/10.1038/srep27909.

Sperry, M. F., H. L. Silva, C. F. Balthazar, E. A. Esmerino, S. Verruck, E. S. Prudencio, R. P. C. Neto, M. I. B. Tavares, J. C. Peixoto, F Nazzaro, R. S. Rocha, J. Moraes, A. S. G. Gomes, R. S. L. Raices, M. C. Silva, D. Granato, T. C. Pimentel, M. Q. Freitas, and A. G. Cruz. 2018. Probiotic Minas Frescal cheese added with L casei 01: Physicochemical and bioactivity characterization and effects on hematological/biochemical parameters of hypertensive overweighted women-A randomized double-blind pilot trial. J. Funct. Foods 45:435-443. https://doi.org/10.1016/j.jff.2018.04.015.

Wright, J. M., V. M. Musini, and R. Gill. 2018. First-line drugs for hypertension. Cochrane Database Syst. Rev. 4:CD001841.

Zakharenko, A. M. A. B. Engin, V. V. Chernyshev, V. V. Chaika, S. M. Ugay, R. Rezaee, G. Karimi, V. A. Drozd, A. V. Nikitina, S. F. Solomennik, O. R. Kudryavkina, L. Xin, Y. Wenpeng, M. Tzatzarakis, A. M. Tsatsakis, and K. S. Golokhvast. 2017. Basophil mediated pro-allergic inflammation in vehicle-emitted particles exposure. Environ. Res. 152:308-314. https://doi.org/10.1016/j .envres.2016.10.031. 